\title{
APLIKACE METODY VÍCEROZM'rRNÉ HODNOCENÍ KLASTROVÝCH INICIATIV
}

APPLICATION OF MULTIDIMENSIONAL EVALUATION METHOD OF CLUSTER INITIATIVES

\author{
Ing. Mgr. Petra MAREĠová, Ph.D. \\ PROF. Ing. KAMIL KULA, Ph.D. \\ Katedra ekonomie $\mid$ Department of Economics \\ Fakulta informatiky a managementu Faculty of Informatics and Management \\ Univerzita Hradec Králové University of Hradec Králové \\ $\triangle$ Rokitanského 62, 50003 Hradec Králové, Czech Republic \\ E-mail: petra.maresova@uhk.cz,kamil.kuca@uhk.cz
}

\begin{abstract}
Anotace

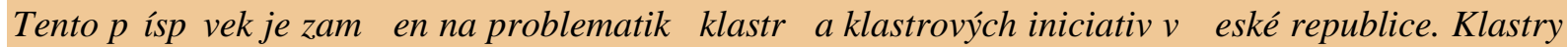
jsou povaǵbvány za významnou a pŚ́nosnou formu spolupráce podnikT, výzkumných institucí, institucí terciárního vzdhávání a dalợch pŚidruğ́ných organizací, která vğem zapojeným úlastník丁m umoớkují, na základ门 kooperace, získat konkuren! ní výhodu oproti ostatním subjekt $\mathrm{T} m$ p 丁sobícím

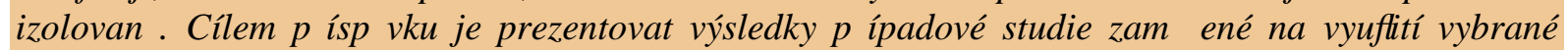
metody pro hodnocení výkonnosti klastrT. Tato studie byla zpracována pro HIT Cluster za pouğití

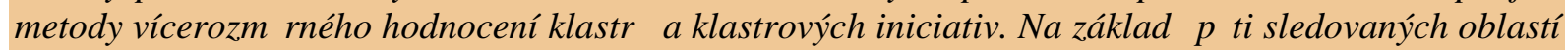
je zhodnoceno fungování tohoto klastru a jsou popsány jeho silné a slabé stránky. Za silné stránky lze povaǵvvat sdílení a pŚnenos informací. Dalò velké pozitivum je schopnost ḷ erpat dotace a spolupráce (sice ne na optimální úrovni) v oblasti inovací. Negativní jev v klastru je nerovnom クná aktivita jeho ! lenT. Situace v HIT klastru odpovídá úrovni stavu klastrT $v$ L eské republice.
\end{abstract}

\section{Klílová slova}

klastry, vícerozm Пné hodnocení klastrT, pŚipadová studie

\section{Anotace}

The paper focuses on the issue of evaluating the performance of clusters in Czech Republic. Clusters are considered as important and valuable form of cooperation between enterprises, research institutions, tertiary institutions and other related organizations, which enable to all participants gain competitive advantage over other isolated subjects. The aim of this paper is to present the results of a case study on the use of method: Multidimensional Evaluation of Clusters and Clusterâs Initiatives. This study was prepared for the HIT Cluster (Hradecky informa! $n$ 円technologicky klastr). Based on five monitored areas the strengths and weaknesses of the cluster are described. As strengths can be seen sharing and transfer of information. Another big positive benefit is the ability to draw the subsidies and cooperation (although not at an optimum level) in the area of innovation. Negative phenomenon is unequal activity of its members in the cluster. The situation in the HIT cluster corresponds to the situation of other existing clusters in the Czech Republic.

\section{Key words}

regional development, clusters, multidimensional evaluation of clusters

JEL classification: $M 2, M 21$ 
Úvod a teoretická východiska

V minulosti se jako dominantní faktory pro dosaǵení konkuren! ní výhody projevovaly materiální vstupy. V soul asné dobク se ve spole! nosti výraznךprosazují faktory nehmotné, intelektuální, jako hlavní konkuren! ní výhoda v rámci globalizace (BednáŚová, 2007). Klastry jsou jedním z nástrojT, který je povaǵ́ván za prostŚedek vedoucí k ekonomickému rTstu.

Existuje mnoho charakteristik pojmu klastr, pŚ| emǵ mezi nejznám円ğ patŚ definice M. Portera, který ve své knize Konkuren! ní výhoda národT uvádí (Porter, 1990): AKlastry jsou místní koncentrace vzájemnク propojených firem a institucí v konkrétním oboru.ñ. Podle Zelené knihy klastrových iniciativ (2006) se klastry skládají ze spolẹ̣ nクumísthých a vzájemnクpropojených prTmyslových odv hví, vlády, akademie obce, finan! ních institucí a institucí pro spolupráci. OECD ve své definici vymezuje klastry jako sítク vzájemnク provázaných podnikT, institucí produkujících znalosti, podpTrných institucí a zákazníkT propojených do výrobního Śethece, který vytváŚ pŚdanou hodnotu. Klastrové iniciativy jsou podle Zelené knihy klastrových iniciativ organizovaný výkon podporující r丁st a konkurenceschopnost klastrT v rámci regionu, rozvoj firem v klastru, státu a/nebo výzkumných spole! nostech (Znalostní platforma klastrové iniciativy, 2012). Klastrové iniciativy tedy vznikají

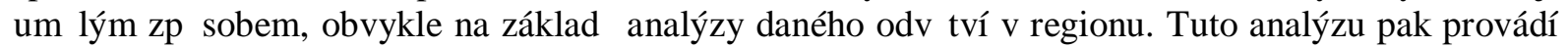
vládní, rozvojové nebo nĐaké specializované firmy.

DTJody podnikatelských subjektT, prol být ! lenem klastru, mohou být rTzné. Primárním cílem !̣ asto bývá posílení pozice $\mathrm{v}$ daném regionu, posílení exportu a výkonnosti (zpravidla prostŚednictvím aplikace poznatk丁 ve výzkumu a vývoji, inovací a transferu technologiî), pŚstup $\mathrm{k}$ informacím a vzdクávání. Klastry mají vliv na zlepg̉ování konkurenceschopnosti a dosahování vyğğ výkonnosti prostŚdnictvím lepğho pŚstupu ke specializovaným dodavatelTm, technologiím, informacím a vyğğho inoval ního potenciálu spolupracujících firem (Porter, 1990). Vznik klastrT v L̦R byl dTsledek jednak pŚrozených procesT, ale také iniciativ regionálních agentur, univerzit !̣i odborných asociací (Pavelková, Jiṛ íková, 2008). V souḷ asnosti existuje v L̦eské republice 62 klastrT a Evropská klastrová observatoŚ(European Cluster Observatory; ECO) statisticky eviduje v Evrop více neǵ 2 000 klastrT. ÚroveŔ ḷ eských klastrT byla v roce 2013 porovnávána s dalğmi klastry v EU pomocí benchmarkingové analýzy. U sledovaných klastrT byla posuzována jejich zralost, kvalita a stabilita klastrového týmu a stabilita ! lenské základny klastru. V této oblasti byly identifikovány silné stránky ! eských klastrT ve stabilitり! lenské základny, které jednozna! nクsouvisejí s !̣ astým pŚmým kontaktem klastrového manaǵera $\mathrm{s}$ ! leny klastru, vysokou mírou spolupráce mezi ! lenskými subjekty a jasnou strukturou rozdクení rolí v Śdícím a rozhodovacím procesu. Naopak slabou stránkou je dlouhodobé systematické vzdクávání !l lenT manaǵerského týmu klastru (CzechInvest, 2013). Pouze 17 \% klastrT

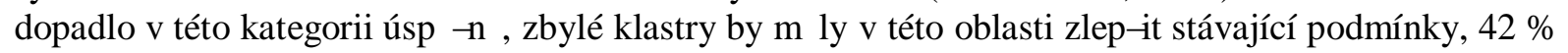

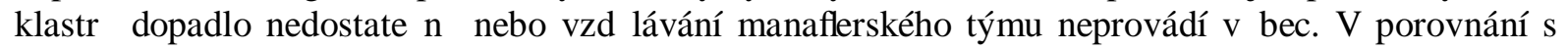
hodnocenými evropskými klastry se jako slabá stránkou více neǵ poloviny klastrT v L eské republice jeví organizace klastrové spolupráce a vytváŚní tzv. pracovních skupin. Obecnクzlepğit by se m円a prezentace klastru na internetu a propagace úsphhT klastru v dalğch médiích(CzechInvest, 2013).

Benchmarking není jedinou moǵnou metodou pro porovnání výkonnosti klastrT. Výkonnost jednotlivých podnikT lze mrśt a Śdit rTznými zpTsoby. Názory odborníkT na pouğití konceptT Śzení a mßśení výkonnosti se rTzní. V soul asné dobクmTǵeme konstatovat, mezi doporul ované metody pro mrśení výkonnosti klastru v domácí nebo zahranil ní odborné literatuŚ jeg̉ ĐpatŚ (Pavelková, 2009): BalancedScorecard (BSC), EconomicValueAdded (EVA), hodnocení klastrT podle ScottishEnterprise. Dalğ metodou pro hodnocení klastrT je metoda vícerozm †̧ného hodnocení klastrT a klastrových iniciativ. Ta vychází z l eského prostŚedí a na základりvícekriteriální analýzy variant byla zvolena jako nejvhodnhğ pro podmínky L,R. Pomocí této metody a bylo hodnoceno fungování Czech Stone Clusteru (Mareġová, Jaǵková, 2012). Oblasti hodnocení jsou:

- hodnocení výkonnosti jednotlivých subjektT zapojených do ḷnnosti klastru (zejména !̣ lenských firem),

- hodnoceni efektivnosti jednotlivých l़ inností realizovaných v klastru,

- hodnoceni výkonnosti klastru jako celku, 
- hodnocení úl innosti Śzeni klastru (klastrové iniciativy),

- hodnocení klastrové politiky regionu/státu (a jeho Âvýkonnostiñ).

\section{Metodika}

V textu je zpracována pŚpadová studie na informaḷn n technologický HIT klastr (Hradecký informa! nクtechnologický klastr), který se nachází v Královéhradeckém kraji v L Leské republice. HIT klastr je zájmovým sdruǵení právnických osob na území Královéhradeckého kraje, které podnikají v

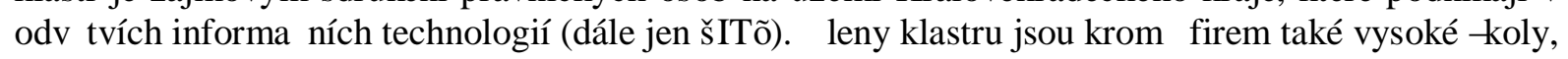
stŚední ǵkoly a nestátní neziskové organizace, které se thnito technologiemi zabývají. V rámci pŚpadové studie byla nejprve provedena analýza dostupných materiálT na webových stránkách klastru, poté probゆlo dotazníkové getŚní mezi ḷ leny klastru. Na dotazníkové getŚnéní odpovídalo 17 ! lenT klastru (z celkového poḷ tu 18 |̣ lenT), z toho jedna vysoká g̉kola, stŚdní g̉kola a technologické centrum Hradec Králové. Ostatní respondenti jsou podnikatelské subjekty.

Otázky také odpovídaly struktuŚ phi hodnocených oblastí tak, jak jsou popsány v metodク vícerozm/jného hodnocení klastrových iniciativ. Dotazníky byly, po získání kontakt丁 na aktuální !̣leny klastru elektronicky distribuovány, a to s vyugóitím bezplatné uğivatelské licence easyresearch.biz. Dotazníkové get klastru, který byl zamฬśsen zejména na interpretaci získaných výsledkT. Dotazníkové getśsení probíhalo $\mathrm{v}$ roce 2012.

\section{Hodnocení výkonnosti HIT klastru - pŚpadová studie}

\subsection{Základní charakteristika HIT klastru}

L̦lenové klastru jsou právnické osoby, z toho 14 firem, univerzita, stŚdní ǵkola a jedna nezisková organizace. Hradecký IT klastr sdruǵuje právnické osoby podnikající v oblasti informal ních technologií a dalğch navazujících sluǵeb, vysoké a stร́dní gokoly a nestátní organizace, které se informa! ními technologiemi zabývají. Cílem sdruğení je zejména výzkum, vývoj, inovace, spolupráce s vysokými a stŚdními ǵkolami a výzkumnými institucemi, propagace odvngí IT a poradenství,

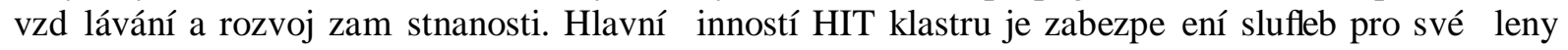
a rozvíjení obchodních moǵností v tḩhto oblastech: rozvoj lidských zdrojT, marketing, sdílení kapacit, vývoj a inovace.

\subsection{Hodnoceni výkonnosti jednotlivých subjektT zapojených do ḷinnosti klastru (zejména !llenských firem)}

Do hodnocení výkonnosti jednotlivých subjekt丁 bylo zaŚzeno hodnocení konkurenceschopnosti ve svém oboru, !l lenství v dalğch sdruǵeních, zamḩ̧tnávání osob znevýhodnhných na trhu práce a vzájemné hodnocení aktivity v rámci klastru. Z hlediska síly konkurence v IT oboru nejvíce !lenT odpov hạo, ǵe shledává silnou konkurenci (59\%), zav velmi silnou ji povaǵuje $24 \%$ a slabou $18 \%$ respondentT. Vlastní konkuren! ní výhodu firmy spatŚijí v tḩhto oblastech:

- vhğ znalost lokálního trhu, regionální pŚsluğhost,

- orientace na pŚdanou hodnotu pro zákazníka,

- spojování IT a marketingu, servis, produkty,

- technologická vyspクost Śǵení, cenová politika,

- flexibilita, operativnost,

- dlouhodobá úzká specializace,

- stabilita, spolupráce, spolehlivost,

- expertní znalosti.

Firmy v klastru jsou také aktivní pŚ zamß̧tnávání osob, které jsou n円akým zpTsobem znevýhodnhy na trhu práce. Nejvíce firem zamß̧̧nává ğeny na rodil ovské dovolené (59\%), dále seniory (29\%) a 


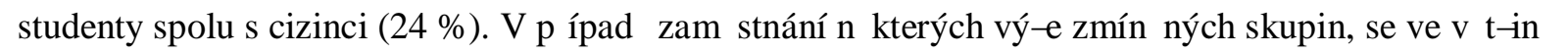
pŚpadT jedná o !̣ ásteḷ ný úvazek. U cizincT a studentT o stáǵe nebo brigády. Nhkteré firmy (pouze 2) zamḩ̧tnávají i na plný úvazek. Firmy v HIT klastru jsou také mnohdy !̣ leny jeğĐdalğch zájmových sdruğení (59\%), coǵukazuje na to, ǵe firmy vnímají pŚnos kooperace a spolupráce s dalğmi subjekty. $\mathrm{Na}$ druhou stranu firmy v klastru dokázali velmi jednoznal nク oznal it 3 nejaktivnクg் ! leny klastru (GIST, Ortex, UHK) coǵukazuje na nevyrovnanost aktivity !̣ lenských firem. Tato nerovnováha byla i potvrzena pŚ rozhovoru s pŚdsedou klastru.

\subsection{Hodnoceni efektivnosti jednotlivých l̦inností realizovaných v klastru}

V této !̣́sti je pozornost zamrśena na spolel né inovaḷ ní aktivity, výzkumné aktivity a propagaci. Respondenti byli tázání na to, jak jsou spokojeni s thmito aktivitami v rámci klastru jako celku. $59 \%$ firem vy!̣ leŔuje své kapacity na vlastní výzkumnou l̦ innost. Z rozhovoru se zástupcem klastru bylo zjiğho, ǵe mezi | leny klastru błğ́ projekty aplikovaného experimentální ho výzkumu. Do budoucna je snaha o spole! né získávání certifikací na bezpel nost. Projektu se musí úl astnit minimálnך 3 ! lenové, aby mohl být projektem klastru, tuto podmínku není obtíǵné pro klastr splnit. V hodnocení této oblasti | leny klastru se ukazují jistá slabá místa, zejména pasivita $n$ hterých firem, které se pŚpadnクjou ochotny zapojit, ale s velice nízkou mírou vlastní iniciace. Situace HIT klastru je z hlediska vyugóití propagace pŚses webové pomクnnクpŚznivá. Lze na nich nalézt aktuální údaje v Śidu týdnT. Z hlediska hodnocení spole! né propagace !̣ leny klastru je situace vnímána jako stśdnndobrá.

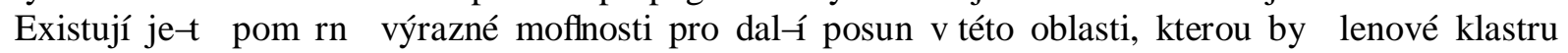
vítali. Na druhou stranu uǵ tak jak je situace nastavena, je vnímána mnohými !̣ leny pozitivnク protoǵe

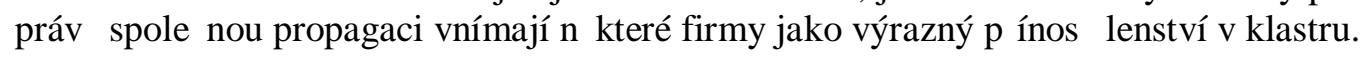

\subsection{Hodnoceni výkonnosti klastru jako celku}

V této oblasti je zamrśena pozornost na silné a slabé stránky fungování klastru jako celku. Mezi pŚnosy ! lenství v klastru patŚ:

- výmク̉a zkuǵeností, sdílení znalostí a informací,

- získání nových kontaktT,

- dobré vztahy s regionálními IT firmami,

- výmha zkuǵeností s ll leny klastru (v oblasti vnitrofiremního ǵivota),

- rozvoj znalostí zamß̧tnancT pracujících na spole! ných projektech,

- výmhia zkuǵeností, sdílení znalostí a informací,

- získání nových kontaktT,

- dobré vztahy s regionálními IT firmami,

- spolupráce v rámci výzkumu,

- kontakty na potenciální zamß̧tnance,

- informace o fungování podobných firem,

- informace o nových technologiích,

- nové pracovní metody,

- sdílení IT kapacit,

- podpora marketingu firmy,

- zdroj nových obchodních aktivit,

- rozğŚní znalostí trhu,

- vyğg zisky.

Mezi oblasti, které jsou vnímány, jako slabé stránky fungování klastru patŚ:

- nízká úroveŔkomunikace a pŚnosu informací,

- nejsou sdíleny zdroje (odborníci),

- rTzné nasazení/pŚnos |lenT,

- neexistence spole! ných zakázek,

- málo neformálních aktivit,

- rTzné zázemí a moǵnosti l lenT,

- sloǵité hledání koncensu s ! leny klastru,

- nedodróování termínT v rámci projektT,

- neochota uvolŔovat finan! ní zdroje na spolel né aktivity.

Dalğ významné faktory ovlivŔující fungování a ! innosti klastru jako celku jsou podle !̣ lenT klastru:

- povinný VaV charakter projektT,

- spole! ný dotal ní projekt je vysoce rizikový,

- náklady na administrativu klastru. 
Mezi oblasti, které by mohly zlepğit fungování klastru a které by jednotlivé firmy vítaly, patŚ:

- flexibilnクğ pravidla dotal ních programT

- vnğ adresnost poskytování dotací, moğnost vylouḷ it slabého ! lena se slabým projektem bez vlivu na sníǵení dotace na kvalitní projekty

- zjednoduǵení a stabilita pravidel ze strany MPO

- zvýǵení propojenosti jednotlivých !l lenT klastru.

- zlepġení komunikace a obeznámenosti o fungování klastru. Více akcí (oficiálních i neoficiálních) uskutel Ŕovaných pod hlavil kou klastru - setkání, workshopy, konference, prezentace.

\subsection{Hodnoceni ú|linnosti Śzeni klastru (klastrové iniciativy)}

Jirl íková identifikovala jako klí! ové faktory pro rozvoj klastrT v Ḷeské republice kvalitní management klastrT, zajig̉ hií finan! ních zdrojT a fungující networking (Pavelková, Jirl íková, 2008). DTleğitá je také schopnost dosahovat spolel né cíle a vytvoŚení atmosféry dTvクy. Respondenti byli proto dotazováni na vzájemnou komunikaci a organizování aktivit v klastru.

Z hlediska pŚmé komunikace dochází k setkávání výkonné rady klastru jednou za mß̧íc, pŚdsedkynク klastru je v kontaktu s !̣ leny dennךa ḷ lenové uvedli, ğe se mezi sebou potkávají s frekvencí jednou za tŚ mḩ̧íce. L̦as, který vĐhovali aktivitám klastru za poslední rok, jsou znázornhyy v tabulce !. 1. Necelá polovina !̣ lenT uvedla, ǵe aktivitám klastru vĐ̧ovala 6-19 dní za poslední rok, výsledky v tabulce lze povaǵovat za spíǵe negativní a aktivitu v rámci klastru nízkou.

Tab. 1: L̦as vMovaný aktivitám klastru za poslední rok

\begin{tabular}{|l|l|l|l|}
\hline \multicolumn{3}{|l|}{ pol et dní } & \multicolumn{2}{l|}{ pol et hodin dennך } \\
\hline do 5 dní & $18 \%$ & do 2 hodin & $47 \%$ \\
\hline 6 aǵ 19 & $47 \%$ & $3 a g ́ 6$ & $24 \%$ \\
\hline 20 dní & $29 \%$ & více neǵ6 & $29 \%$ \\
\hline
\end{tabular}

To co mezi sebou !̣ lenové sdílení jsou zejména zamß̧̧nanci a kontakty, nejménクpak technologie a finan! ní zdroje. Za nejvýznamnநğ pro fungovaný klastr je povaǵováno sdílení znalostí o pracovní síle, trhu, dodavatelích a fungování klastru jako celku.

\subsection{Hodnoceni klastrové politiky regionu/státu}

V Ḷeské republice pŚedstavují strukturální fondy EU nejdநleǵitクg̉ sloǵku financování klastrT, jak z hlediska vlastní ! innosti klastrových iniciativ, tak dalğch projektT zaloǵené organizal ní jednotky klastru. V rámci strukturálních fondT byl pro období 2004 ï 2006 nejdTleğit’ğm finan! ním zdrojem pro klastry a klastrové iniciativy Opera! ní program PrTmysl a podnikání (OPPP), program Klastry. Na uvedený program navazoval pro období 2007 ï 2013 Operal ní program Podnikání a inovace (OPPI), program SPOLUPRÁCE ï KLASTRY, který je také administrován MPO (Mareġová, Jağková, 2012).

Na úrovni státu, se o klastrové iniciativy stará napŚklad Agentura pro podporu podnikání CzechInvest a Ministerstvo prTmyslu a obchodu (MPO). Klastrovou politikou se zabývají následující strategické dokumenty, a to Strategie hospodáŚského rŢstu LLR. Strategie regionálního rozvoje na 2007 ï 2013, Strategie rozvoje krajT, Národní inoval ní strategie ! eské republiky, Národní rozvojový plán l़ eské republiky 2007 ï 2013, Národní referen!̣ ní strategický rámec L̦R 2007 ï 2013.

Královehradecký kraj, ve kterém se firmy z HIT klastru nachází, nevytváŚ dotal ní programy ur! ené pŚmo pro klastry. Klastry ovǵem mohou vyuğ́t program Regionální inovaḷní fond Královéhradeckého kraje ï Inoval ní vouchery, které slouǵ̛ transferu znalostí mezi výzkumnými institucemi a podniky. Inoval ní vouchery jsou urḷ ené pro malé a stŚ́éní podniky se sídlem v Královehradeckém kraji. Výǵe dotace je 50000 - $150000 \mathrm{~K}$ ! a moǵný podíl dotace je $100 \%$ 
zpTsobilých výdaj丁 projektu. NapŚklad Hradecký IT klastr byl velice efektivní pŚ získávání Inoval ních voucherT 2010 (realizace rok 2011). Klastru samotnému byla schválena dotace ve výğ $130000 \mathrm{~K}$ ! na Optimalizaci interních procesT klastru a dalğ ! tyŚ vouchery, v celkové hodnoth $560000 \mathrm{~K} \mid$, byly pŚdクeny jeho !̣ lenským firmám. Z jedenácti podaných ǵádostí o Inoval ní voucher 2010 byly schváleny vǵechny (Mareǵová, Jaǵková, 2012). V roce 2013bylo 12 subjektT z klastru schopno vyuğ́vat n円aký dotal ní titul.

\section{Graf 1: Hodnocení efektivity dota!̣nich programT HIT klastrem}

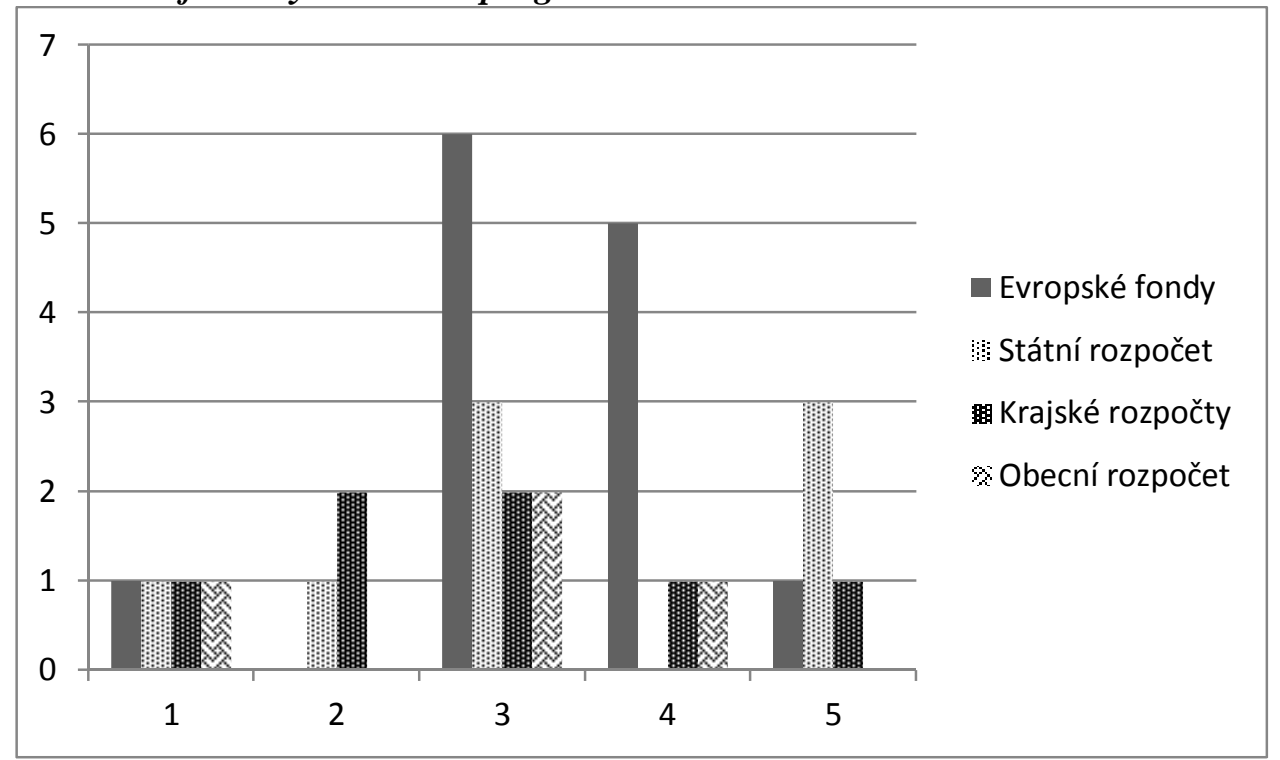

(ǵála 1: neefektivní - 5: efektivní)

Zdroj: vlastní výzkum

Firmy v HIT klastru se také vyjadŚovaly k tomu, jak vnímají efektivitu dotal ních programT v Ḷeské republice. Relativnク nejlépe dopadlo hodnocení vyugóití penłz ze strukturálních fondT EU (na bodovací stupnici získalo hodnocení 3 a 4). Tento výsledek lze mTǵe být ovlivnhn tím, ǵe vhğna získaných dotaḷ ních titulT je práv门z ESF. Obecní a krajské rozpol ty byly hodnoceny hTŚs (graf !. 1).

\section{Shrnutí}

HIT klastr byl hodnocen z hlediska phi sledovaných oblastí v rámci metody vícerozm/gné hodnocení klastrových iniciativ. NapŚ! vǵemi phji oblastmi lze charakterizovat ur!̣tá pozitiva a negativa v klastru. Mezi pŚnosy ! lenství v klastru patŚ pŚdevğm vým円ha zkuǵeností, sdílení znalostí a informací, získání nových kontaktT a navázání dobrých vztahT s regionálními IT firmami. Za slabou stránku fungování klastru lze oznal it pom円nク nízkou pŚmou participaci mnohých ! lenT na jeho fungování (za nejaktivnクğ bylo z 19 |̣ lenT oznal eno jen 5 ! lenT, coǵ vğkk nevyluḷje moğnost ostatních být aktivn円g்). Samotní ḷ lenové povaǵují za nejslabğ stránky nedostatel nou vzájemnou znalost jednotlivých ! lenT, chybクící zadávání úkolT a z toho plynoucí nízkou míru spolupráce v pŚpadクskon! ení b huu dotal ních titulT. Silné a slabé stránky lze shrnout následovnク

a) Silné stránky fungování klastru:

- Schopnost lerpat dotace z operal ních programT.

- aktivní spolupráce s akademickou sférou,

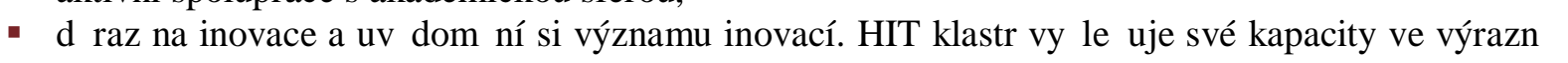
vyğğ míś (59\%),

- moǵnost spolel né propagace, 11 ḷ lenT HIT klastr uvedlo, ǵe jedna z forem propagace je sponzoring kraje,

- stabilní l lenská základna.

b) Slabé stránky fungování klastru

- Nízká úroveŔinoval ních aktivit.

- Nízká míra komunikace mezi ! leny klastru a participace na aktivitách klastru. 
- Nerostoucí poḷ et l lenských podnikT.

- Neschopnost se vzájemn Đpropagovat na svých webových stránkách.

- PŚtíǵenost pŚdsedy klastru.

- nevyuğivání zdaleka vğech moǵností ! erpání dotací. Nevíce jsou vyuğ́vány strukturální fondy EU.

PŚ pohledu na situaci HIT klastru a na výsledky benchmarkingové studie na klastrech v Ḷeské republice [odkaz] lze konstatovat, ǵe tyto dvク analýzy vykazují podobné výsledky. Oblasti se ve

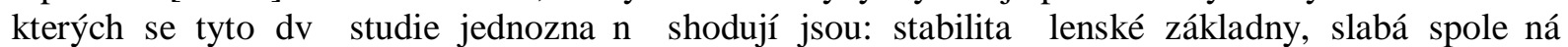
prezentace, nízká aktivita pracovních skupin a stŚední úroveŔ inovací. V HIT klastru je navíc negativnクhodnocena nerovnom hná aktivita ! lenT.

\section{Závî}

V probíhajícím procesu globalizace a vzniku a rozvoje nadnárodních firem, je pro menğ podniky jednou z hlavních moǵností získání konkuren!̣ ní výhody spolupráce. Jednou z forem takovéto spolupráce jsou i klastry, které jsou stále !̣astým tématem regionálních rozvojových dokumentT a strategií a dostává se jim stále vhğho prostoru, jelikoǵ jsou povaǵovány za faktor, který mTǵe významn Đovlivnit rozvoj regionu. V souvislosti s konkurenceschopností jsou jednozna!̣ nクspojovány inovace, výzkum a vývoj. I v této oblasti hrají klastry podstatnou roli, jelikoǵ svým p丁sobením vytváŚ podmínky k podnßcování inovací a lepg̉mu vyuğ́vání výzkumu a vývoje.

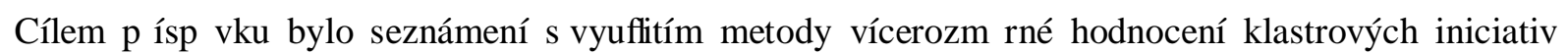
v HIT klastru. Z analýzy vyplynulo, ǵe studovaný klastr splŔuje základní pŚedpoklady ke zvyğbvání konkurenceschopnosti své a svých !̣ lenT. V rámci !̣l lenT klastru probíhá sdílení a pŚenos informací, coǵje povaǵováno za významný pŚnos pro vğechny ! leny. Dalğ velké pozitivum je schopnost ! erpat dotace a spolupráce (sice na optimální úrovni) voblasti inovací. Negativní jev v klastru je nerovnomদnná aktivita ! lenT, kdy firmy sami uvedli tŚ nejaktivnクğ !̣leny klastru a dále byla

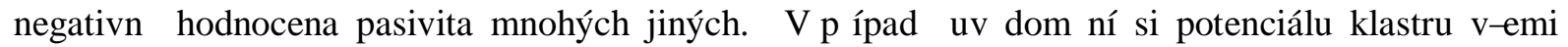
!l leny klastru a zlepǵení spolupráce, mTǵe být dále zvyǵována ziskovost, konkuren! ní výhoda a postavení na trhu klastru jako celku i jeho ! lenT.

\section{Literatura}

[1] BEDNÁř OVÁ, D., (2007). Inovace a klastry v rozvoji regionT. L̦eské Bud円ovice: Jihol eská univerzita v Leských Bud円ovicích. ISBN 978-80-7040-952-7.

[2] ĆzechInvest, (2013). Mezinárodní srovnání leských klastr]. [online]. Dostupné z: http://www.czechinvest.org/data/files/mezinarodni-srovnani-ceskych-klastru-3878-cz.pdf.

[3] MAREĠOVÁ, P., JAǴKKOVÁ, P., (2012). Aplikace metody vícerozmlnného hodnocení klastrT, Acta Univ. Bohem. Merid., vol. 15, iss. 1, pp. 77-90. ISSN 1212-3285.

[4] PAVELKOVÁ, D. a kol., (2009). Klastry a jejich vliv na výkonnost firem. Praha: Grada. ISBN 978-80247-2689-2.

[5] PAVELKOVÁ, D., JIRḶíKOVÁ, E., (2008). Klastry jako nástroj zvýǵgní konkurenceschopnosti firem, E+M Ekonomie a Management, vol. 11, iss. 3, pp. 62-72.

[6] PORTER, M. E., (1990). Competitive Advantage of Nations. New York: Free Press. ISBN 0-684-84147-9

[7] Znalostní platforma klastrové iniciativy, (2012). [online]. Dostupné z: <http://www.klastrcontrol.cz/index.php?page=odkazycr>

Projekt vznikl za podpory interního specifického projektu Ekonomicko-manaǵgrské aspekty procesT v biomedicín Dna UniverzithHradec Králové. 